\title{
Halitosis: an overview of epidemiology, etiology and clinical management
}

\section{Cassiano Kuchenbecker Rösing(a) Walter Loesche ${ }^{(b)}$}

\footnotetext{
(a) Department of Periodontology, Dental School, Universidade Federal do Rio Grande do Sul, Porto Alegre, RS, Brazil.

(b) Department of Microbiology and Immunology, School of Dentistry, University of Michigan, Ann Arbor, MI, USA.
}

\begin{abstract}
Halitosis is an unpleasant condition that causes social restraint. Studies worldwide indicate a high prevalence of moderate halitosis, whereas severe cases are restricted to around $5 \%$ of the populations. The etiological chain of halitosis relates to the presence of odoriferous substances in exhaled air, especially the volatile sulphur compounds (VSC) produced by bacteria. The organoleptic diagnosis is the gold standard and clinical management includes oral approaches, especially periodontal treatment and oral hygiene instructions, including the tongue. When oral strategies are not successful, referral to physicians is warranted.
\end{abstract}

Descriptors: Halitosis; Epidemiology; Microbiology; Review.

\section{Introduction}

Halitosis is defined as breath that is offensive to others, caused by a variety of reasons including but not limited to periodontal disease, bacterial coating of tongue, systemic disorders and different types of food. ${ }^{1}$ It is one of the most frequent claims from patients to the dentist. ${ }^{2}$

After the decline in the prevalence of oral diseases of major prevalence, Dentistry has given it a closer attention, which should not be considered a cosmetic problem. However, science behind the understanding of halitosis is weak. Several clinical approaches are based strictly on opinions. The present review will focus on different aspects of halitosis, trying to demonstrate the most appropriate evidence to support the approach for its management.

\section{Epidemiology Descriptive studies}

The prevalence of halitosis has been studied in groups of individuals found in different parts of the world in convenience samples. Different assessments and cut-off points are presented. Therefore, precise estimates of the prevalence of halitosis are not possible to obtain. Table 1 describes descriptive epidemiological studies that document the prevalence of halitosis. They indicate that moderate chronic halitosis affects approximately one third of the groups, whereas severe halitosis may involve less than $5 \%$ of the population. It is clear that halitosis is a prevalent problem, and that the dental profession needs to take its responsibility in managing it.
Received for publication on Jul 10, 2011 Accepted for publication on Sep 01, 2011
Corresponding author:

Cassiano Kuchenbecker Rösing

E-mail: ckrosing@hotmail.com 
Table 1 - Summary of descriptive epidemiological studies concerning halitosis.

\begin{tabular}{|c|c|c|c|c|c|}
\hline Author/year & Location & $\mathrm{N}$ & Sampling procedure & Halitosis measurement & Main results \\
\hline $\begin{array}{c}\text { Miyazaki et al., } \\
1995^{3}\end{array}$ & Japan & $\begin{array}{c}2672 \text { government } \\
\text { workers, } \\
18-64 \text { years }\end{array}$ & $\begin{array}{l}\text { Convenience } \\
\text { sample }\end{array}$ & VSC (Halimeter) & $\begin{array}{l}\text { Prevalence of moderate halitosis } \\
\qquad(\geq 75 \mathrm{ppb})=28 \%\end{array}$ \\
\hline $\begin{array}{l}\text { Loesche et al., } \\
1996^{4}\end{array}$ & USA & $\begin{array}{l}270 \text { adults, } \\
60+\text { years }\end{array}$ & $\begin{array}{l}\text { Convenience } \\
\text { sample }\end{array}$ & Self-report & $\begin{array}{c}\text { Prevalence of self } \\
\text { perception }=31 \% \\
\text { Prevalence of halitosis informed } \\
\text { by others }=24 \%\end{array}$ \\
\hline $\begin{array}{l}\text { Frexinos et al., } \\
1998^{5}\end{array}$ & France & $\begin{array}{l}4815 \text { individuals, } \\
15+\text { years }\end{array}$ & $\begin{array}{l}\text { Randomized, } \\
\text { representative }\end{array}$ & Self-report & $\begin{array}{c}\text { Prevalence of self-reported } \\
\text { halitosis }=22 \%\end{array}$ \\
\hline $\begin{array}{l}\text { Söder et al., } \\
2000^{6}\end{array}$ & $\begin{array}{l}\text { Stockholm, } \\
\text { Sweden }\end{array}$ & $\begin{array}{l}1681 \text { adults, } \\
30-40 \text { years, }\end{array}$ & $\begin{array}{l}\text { Randomized, } \\
\text { representative }\end{array}$ & Organoleptic & $\begin{array}{l}\text { Prevalence of severe halitosis } \\
\qquad(\text { score } 5)=2.4 \%\end{array}$ \\
\hline $\begin{array}{l}\text { Nalçaci et al., } \\
2008^{7}\end{array}$ & $\begin{array}{l}\text { Middle Anatolia, } \\
\text { Turkey }\end{array}$ & $\begin{array}{l}628 \text { children, } 7-11 \\
\text { years }\end{array}$ & $\begin{array}{l}\text { Convenience } \\
\text { sample }\end{array}$ & Organoleptic & $\begin{array}{c}\text { Prevalence of } \\
\text { halitosis }=14.5 \%\end{array}$ \\
\hline $\begin{array}{l}\text { Bornstein et al., } \\
2009^{8}\end{array}$ & $\begin{array}{l}\text { Bern, } \\
\text { Switzerland }\end{array}$ & $\begin{array}{l}419 \text { adults, } \\
18-94 \text { years }\end{array}$ & $\begin{array}{l}\text { Randomized, } \\
21 \% \text { response }\end{array}$ & $\begin{array}{l}\text { Self-report, } \\
\text { Organoleptic } \\
\text { and VSC }\end{array}$ & $\begin{array}{c}\text { Prevalence of organoleptic } \\
\text { score } 3+=11.5 \% \\
\text { Prevalence of self-reported } \\
\text { halitosis }=32 \% \\
\text { Prevalence of } \\
\text { VSC } 75+\text { ppb }=28 \%\end{array}$ \\
\hline $\begin{array}{l}\text { Bornstein et al., } \\
2009^{9}\end{array}$ & Switzerland & $\begin{array}{l}626 \text { male } \\
\text { army recruits, } \\
18-25 \text { years }\end{array}$ & $\begin{array}{l}\text { Convenience } \\
\text { sample }\end{array}$ & $\begin{array}{l}\text { Self-report and } \\
\text { clinical analysis }\end{array}$ & $\begin{array}{l}\text { Prevalence of detected chronic } \\
\text { halitosis }=20 \% \\
\text { Prevalence of individuals without } \\
\text { halitosis experience }=17 \%\end{array}$ \\
\hline $\begin{array}{l}\text { Yokoyama et al., } \\
2010^{10}\end{array}$ & Japan & $\begin{array}{l}474 \text { senior high } \\
\text { school students }\end{array}$ & $\begin{array}{l}\text { Convenience } \\
\text { sample }\end{array}$ & $\begin{array}{l}\text { Self report and } \\
\text { clinical analysis }\end{array}$ & $\begin{array}{c}\text { Prevalence of halitosis } \\
\text { experience (anxiety or } \\
\text { consciousness of the problem at } \\
\text { least once) }=42 \% \\
\text { Prevalence of clinically } \\
\text { detectable malodor }=39.6 \%\end{array}$ \\
\hline
\end{tabular}

\section{Associated factors}

A study in Sweden ${ }^{6}$ observed that calculus, plaque and scarce dental visits were significantly correlated to severe halitosis. A Japanese study ${ }^{3}$ correlated periodontitis and tongue coating to VSC scores. Also, severe periodontitis patients presented higher halitosis scores than non-periodontal patients. In the two Swiss studies ${ }^{8,9}$ tongue coating was considered an influencing factor for halitosis. Smoking and periodontal disease were associated with higher halitosis rankings. ${ }^{8}$ Plaque and tongue coating were associated with halitosis. ${ }^{10}$ In children, caries experience and age were associated to malodor. ${ }^{7}$ Whether these associations are causal is not clear.

\section{Etiology}

The etiology of halitosis has been subject to a historical controversy. ${ }^{2}$ Dentistry claimed oral etio- logical factors; however, in order not to undertake the responsibility for treatment, it would sometimes emphasize non-oral causes of halitosis. Thus, the stomach was, for years, blamed for the presence of halitosis. Several studies have demonstrated that the mouth is the origin for the majority of halitosis.,11 Eighty-seven percent of the incoming patients with severe malodor who attended a specialized clinic for halitosis in Belgium ${ }^{11}$ had their problem related to oral factors. Gingivitis and periodontitis accounted for approximately $60 \%$ of the oral factors and the tongue accounted for the other $40 \%$. A subsequent report by the same group ${ }^{12}$ found oral factors as responsible for halitosis in $76 \%$ of 2000 patients. Therefore, Dentistry is responsible for diagnosing and treating halitosis. 


\section{Periodontal inflammation}

The presence of microorganisms and the inflammatory products present in gingivitis/periodontitis are capable of producing odoriferous substances. Cross-sectional studies associated halitosis to the presence of either gingivitis or periodontitis., $3,8,9,11,12$ In vitro and in vivo studies demonstrated the ability of putative periodontal pathogens and products of inflammation to produce volatile odoriferous compounds. . $^{13,14,15,16}$ Therefore, the presence of periodontal inflammation needs to be considered in the management of halitosis.

\section{Tongue coating}

Tongue coating, including bacteria, desquamated cells, and saliva, among others, is one of the important etiological factors of halitosis. A study ${ }^{12}$ demonstrated that tongue coating was associated with halitosis in more than $60 \%$ of 2000 patients of a breath clinic, whether present alone, or with periodontal inflammation. Most studies implicate the coating on the posterior area of the tongue which is consistent with the presence of billions of bacteria, including anaerobes that live there and are capable of producing odoriferous substances. ${ }^{17}$

\section{Microbiology of halitosis}

Bacteria from the saliva, ${ }^{18}$ from plaque removed from gingivitis/periodontitis ${ }^{16}$ as well as from the tongue ${ }^{17}$ produce odoriferous substances in vitro. Intervention studies which achieve a clinically significant effect in reducing halitosis exhibit a reduction in these bacteria. ${ }^{19,20}$ Therefore, the clinical management should also include microbiological targets, with antimicrobial approaches - mechanical and chemical - being part of the strategy.

\section{Non-oral causes of halitosis}

Ear-nose-throat problems such as tonsillitis, sinusitis, the presence of out-of-body material and rhinitis were frequently associated with non-oral halitosis in breath clinics. ${ }^{11,12}$ These studies were unable to find clinically relevant associations of halitosis with gastroenterological problems. However, two studies $^{21,22}$ demonstrated a possible association between gastrointestinal problems and halitosis and that their treatment improves halitosis measurements. Stressful situations also might contribute to increase halitosis. ${ }^{23}$ In some individuals, the complaint of halitosis cannot be associated with either the ability of the clinician to detect odors or with the demonstration of VSC in the exhaled air. This paradoxical situation has been classified as halitophobia, an important psychological problem that needs to be addressed with non-oral clinical strategies. ${ }^{6,12}$

\section{Clinical management Diagnosis \\ Self-assessment}

The patient cannot smell his own breath and relies upon others for this information. It should be emphasized that it is a difficult task to tell someone that he has bad breath. Thus, results from this kind of diagnosis should be interpreted with care. In a breath clinic, ${ }^{11}$ more than $70 \%$ of the patients were advised by others to seek treatment, whereas in another study, ${ }^{4}$ only $24 \%$ of the elders were informed that they harbored bad breath. Of course, differences from study populations might explain the disparity in results (the former being from a breath clinic and the latter from a convenience sample of older individuals). In the study by Bornstein et al., ${ }^{8}$ a weak correlation was observed between self-reported halitosis and clinical measurements.

\section{Organoleptic measurements}

The human nose remains the "Gold Standard" in detecting oral halitosis. The most widely used scoring system for ranking halitosis is the Organoleptic Score popularized by Rosenberg and McCulloch. ${ }^{24}$ The organoleptic measurement depends on a trained examiner that has demonstrated reliability in smelling halitosis. The study by Haas et al. ${ }^{25}$ has demonstrated good levels of reproducibility of breath odor measurements, under a blind evaluation. The reason by which the organoleptic score has been the gold standard for breath measurements rely on the fact that the human nose is capable of smelling and defining as pleasant/unpleasant not only the VSC, but also other organic compounds that come from exhalation and are identified as unpleasant. ${ }^{2}$ 


\section{VSC monitoring}

Objective measurements have always been desired for breath assessments. The most common malodorants detected in halitosis are VSC which include hydrogen sulfide and methyl mercaptans, among others. VSC monitors have been developed, such as the Halimeter (Interscan, Chatsworth, USA) which is used chairside and provides both the patient and the professional an idea of the breath situation. A halimeter score of $\geq 75 \mathrm{ppb}$ is recognized as clearly detected halitosis. It is important to understand that VSC assessment, as well as other breath diagnostic tools are subjected to great variation, especially between different hours of the day, and are strongly affected by confounders. ${ }^{16}$

\section{Microbiologic tests}

The VSC monitors detect from $18 \%$ to $67 \%$ of the odors represented by the organoleptic score. This is because the nose is detecting odors due to many other compounds that are in the intra-oral air as a result of microbial metabolism. Most of these compounds cannot be easily measured, and some such as volatile fatty acids (butyrate, propionate, etc.), diamines (cadaverine, putrescine) and other foulsmelling products can only be measured by laboratory based assays.

An alternative strategy would be to detect in plaque, or in the tongue coating, taken from individuals with halitosis, those bacteria or their enzyme(s) that can produce these compounds. Three species associated with periodontal disease, Treponema denticola, Porphyromonas gingivalis and Tannerella forsythia, produce both VSC and volatile fatty acids. The detection of these bacteria might provide additional information concerning factors contributing to the individual's malodor. These organisms can be detected by the presence of an enzyme(s) that degrades benzoyl-DL-arginine-naphthylamide (BANA), a synthetic trypsin substrate, forming a colored compound. We have adapted this enzyme assay to a 5- to 10-minute chairside test - the BANA Test (BANAMet LLC, Ann Arbor, USA) - that detects the presence of this enzyme(s) in plaque and tongue samples.

The BANA test provides additional information on compounds other than the VSC that contribute to halitosis. Kozlovsky et al. ${ }^{26}$ found that the BANA Test correlated significantly with the organoleptic scores obtained from the whole mouth, the tongue and saliva, but not with the VSC. When multipleregression analyses were performed with the organoleptic scores as the dependent variable, both peak VSC and the BANA scores factored into the regression, yielding significant associations. They conclude that the "BANA test may be a simple, adjunct assay together with volatile sulphide determination in order to provide additional quantitative data which contribute to the overall association with odor-judge estimation."

A connection between BANA-positive bacteria and malodor was observed in English subjects ${ }^{27}$ using BAPNA as the trypsin-like substrate. Seventy eight percent of the isolates from 23 subjects with organoleptic scores $\geq 3$ were BAPNA positive, compared with $35 \%$ to $40 \%$ BAPNA positive isolates in the subjects with organoleptic scores of 2. Subsequently, Stomatococcus mucilaginus, a gram-positive, facultative, cocco-bacillus, was identified as a BAPNA-positive species that is indigenous to the tongue. This indicates that a BANA-positive reaction in the tongue, while indicative of halitosis, is due to the presence of a bacterial flora that may be unique to it.

\section{Treatment}

\section{Periodontal therapy}

Periodontal treatment decreases halitosis. However, studies concerning response to periodontal therapy as the only therapeutic approach for halitosis are scarce and sometimes the effects are limited, especially because other sources of halitosis are not considered. A study by Silveira et al. ${ }^{28}$ demonstrated that a strict supragingival plaque control is able to reduce VSC and organoleptic scores in periodontitis patients. The studies performed in breath clinics have also demonstrated the ability of periodontal treatment measurements to reduce halitosis. ${ }^{11,12}$

\section{Approaches directed to tongue coating}

Several studies have demonstrated that reducing bacteria on the dorsum of the tongue will dimin- 
ish halitosis. A study concluded that tongue cleaning was one of the most important approaches for halitosis. ${ }^{29}$ A systematic review ${ }^{30}$ demonstrated the potential of tongue cleaning, however the evidence was not convincing. Also, a Cochrane systematic review $^{31}$ demonstrated that there is a little superiority of tongue scrapers as compared to brushing in reducing halitosis. Therefore, tongue cleansing is one of the components and should never be a sole treatment for halitosis.

\section{Antimicrobials}

Since the presence of microorganisms from oral biofilms is responsible for producing malodor, any type of treatment approach that has impact in the oral microbiota has the potential of reducing halitosis. Mouthrinses, especially chlorhexidine and cetilpyridinium chloride have been effective in reducing halitosis. ${ }^{20,32}$ In addition, the use of dentifrices has also been studied. Triclosan containing dentifrices, for example, have demonstrated an interesting potential in reducing VSC. ${ }^{33}$

\section{Medical approaches}

If oral approaches are not successful in reducing/ eliminating halitosis, patients should be referred to a physician. If the medical causes cannot be suspected, the first professional to be referred is the otorhinolaryngologist, followed by the gastroenterologist. If halitophobia is considered, a psychologist or phsy-

\section{References}

1. American Academy of Periodontology. Glossary of Periodontal Terms. 4th ed. Chicago: American Academy of Periodontology; 2001. 56 p.

2. Loesche WJ, Kazor C. Microbiology and treatment of halitosis. Periodontol 2000. 2002 Apr;28:256-79.

3. Miyazaki H, Sakao S, Katoh Y, Takehara T. Correlation between volatile sulphur compounds and certain oral health measurements in the general population. J Periodontol. 1995 Aug;66(8):679-84.

4. Loesche WJ, Grossman N, Dominguez L, Schork MA. Oral malodour in the elderly. In: van Steenberghe D, Rosenberg M, editors. Bad breath: a multidisciplinary approach. Leuven: Leuven University Press; 1996: 181-94.

5. Frexinos J, Denis P, Allemand H, Allouche S, Los F, Bonnelye G. [Descriptive study of digestive functional symptoms in the chiatrist should be included. ${ }^{11,12,21,22,34}$

\section{Masking agents}

When it is not possible to direct the treatment approach to the cause, masking agents have been developed to decrease the odor. The use of chewing gum may decrease halitosis, especially through increasing salivary secretion. ${ }^{35}$ Mouthrinses containing chlorine dioxide and zinc salts have a substantial effect in masking halitosis, not allowing the volatilization of the unpleasant odor. ${ }^{20,35}$ These approaches should be only used temporarily in order to improve satisfaction of the patient.

\section{Summary and Conclusions}

The present review demonstrated that halitosis is a common problem impacting individuals at all ages. The main etiological factors include bacteria in the oral cavity related especially to periodontal diseases and the dorsum of the tongue. Medical aspects include ear-nose-throat and gastroenterological problems. Since the majority of halitosis is related to the mouth, the dental team should lead the treatment, performing dental/periodontal treatment and personalized oral hygiene instructions. Antimicrobials have the potential of reducing halitosis and masking agents should be used temporarily. The literature, especially with randomized clinical trials, is scarce and additional studies are needed.

French general population]. Gastroenterol Clin Biol. 1998 Oct;22(10):785-91. French.

6. Söder B, Johansson B, Söder PO. The relation between foetor ex ore, oral hygiene and periodontal disease. Swed Dent J. 2000 Mar;24(3):73-82.

7. Nalçaci R, Dülgergil T, Oba AA, Gelgör IE. Prevalence of breath malodour in 7-11-year-old children living in Middle Anatolia, Turkey. Community Dent Health. 2008 Sep;25(3):173-7.

8. Bornstein MM, Kislig K, Hoti BB, Seemann R, Lussi A. Prevalence of halitosis in the population of the city of Bern, Switzerland: a study comparing self-reported and clinical data. Eur J Oral Sci. 2009 Jun;117(3):261-7.

9. Bornstein MM, Stocker BL, Seemann R, Bürgin WB, Lussi A. Prevalence of halitosis in young male adults: a study in swiss 
army recruits comparing self-reported and clinical data. J Periodontol. 2009 Jan;80(1):24-31.

10. Yokoyama S, Ohnuki M, Shinada K, Ueno M, Wright FA, Kawaguchi Y. Oral malodor and related factors in Japanese senior high school students. J Sch Health. 2010 Jul;80(7):34652.

11. Delanghe G, Ghyselen J, Feenstra L, van Steenberghe D. Experiences of a Belgian multidisciplinary breath odour clinic. Acta Otorhinolaryngol Belg. 1997; Jan;51(1):43-8.

12. Quirynen M, Dadamio J, Van den Velde S, De Smit M, Dekeyser C, Van Tornout M, et al. Characteristics of 2000 patients who visited a halitosis clinic. J Clin Periodontol. 2009 Nov;36(11):970-5.

13. Yoneda M, Masuo Y, Suzuki N, Iwamoto T, Hirofuji T. Relationship between the $\beta$-galactosidase activity in saliva and parameters associated with oral malodor. J Breath Res. 2010 Mar;4(1):17-8.

14. Kleinberg I, Codipilly M. Modeling of the oral malodor system and methods of analysis. Quintessence Int. 1999 May;30(5):357-69.

15. Salako NO, Philip L. Comparison of the use of the Halimeter and the Oral Chroma ${ }^{\mathrm{m}}$ in the assessment of the ability of common cultivable oral anaerobic bacteria to produce malodorous volatile sulfur compounds from cysteine and methionine. Med Princ Pract. 2011 Jan;20(1):75-9.

16. De Boever EH, De Uzeda M, Loesche WJ. Relationship between volatile sulfur compounds, BANA-hydrolyzing bacteria and gingival health in patients with and without complaints of oral malodor. J Clin Dent. 1994;4(4):114-9.

17. Kazor CE, Mitchell PM, Lee AM, Stokes LN, Loesche WJ, Dewhirst FE, et al. Diversity of bacterial populations on the tongue dorsa of patients with halitosis and healthy patients.J Clin Microbiol. 2003 Feb;41(2):558-63.

18. Takeshita T, Suzuki N, Nakano Y, Shimazaki Y, Yoneda M, Hirofuji T, et al. Relationship between oral malodor and the global composition of indigenous bacterial populations in saliva. Appl Environ Microbiol. 2010 May;76(9):2806-14.

19. Shinada K, Ueno M, Konishi C, Takehara S, Yokoyama S, Zaitsu T,et al. Effects of a mouthwash with chlorine dioxide on oral malodor and salivary bacteria: a randomized placebocontrolled 7-day trial. Trials. 2010 Feb 12;11:14.

20. Fedorowicz Z, Aljufairi H, Nasser M, Outhouse TL, Pedrazzi V. Mouthrinses for the treatment of halitosis. Cochrane Database Syst Rev. 2008;8(4):CD006701. [citado 27 jun 2011]. Disponível em: http://cochrane.bvsalud.org/cochrane/main. php?lib=COC\&searchExp = Mouthrinses $\% 20$ and $\% 20$ for $\% 20$ and $\% 20$ the $\% 20$ and $\% 20$ treatment $\% 20$ and $\% 20$ of $\% 20$ and $\% 20$ halitosis\&lang=pt.

21. Moshkowitz M, Horowitz N, Leshno M, Halpern Z. Halitosis and gastroesophageal reflux disease: a possible association. Oral Dis. 2007 Nov;13(6):581-5.
22. Kinberg S, Stein M, Zion N, Shaoul R. The gastrointestinal aspects of halitosis. Can J Gastroenterol. 2010 Sep;24(9):5526.

23. Queiroz CS, Hayacibara MF, Tabchoury CP, Marcondes FK, Cury JA. Relationship between stressful situations, salivary flow rate and oral volatile sulfur-containing compounds. Eur J Oral Sci. 2002 Oct;110(5):337-40.

24. Rosenberg M, McCulloch CA. Measurement of oral malodor: current methods and future prospects. J Periodontol. 1992 Sep;63(9):776-82.

25. Haas AN, Silveira EM, Rösing CK. Effect of tongue cleansing on morning oral malodour in periodontally healthy individuals. Oral Health Prev Dent. 2007;5(2):89-94.

26. Kozlovsky A, Gordon D, Gelernter I, Loesche WJ, Rosenberg M. Correlation between the BANA test and oral malodor parameters. J Dent Res. 1994 May;73(5):1036-42.

27. van Steenberghe D, Rosenberg M. Bad Breath: a Multidisciplinary Approach. 1st. Leuven: Leuven University Press; 1996. Assessment of impressed toothbrush as a method of sampling tongue microbiota; p. 123-34.

28. Silveira EMV, Piccinin FB, Gomes SC, Oppermann RV, Rösing $\mathrm{CK}$. The effect of gingivitis treatment on the breath of chronic periodontitis patients. Oral Health Prev Dent. Forthcoming 2011.

29. Faveri M, Hayacibara MF, Pupio GC, Cury JA, Tsuzuki CO, Hayacibara RM. A cross-over study on the effect of various therapeutic approaches to morning breath odour. J Clin Periodontol. 2006 Aug;33(8):555-60.

30. Van der Sleen MI, Slot DE, Van Trijffel E, Winkel EG, Van der Weijden GA. Effectiveness of mechanical tongue cleaning on breath odour and tongue coating: a systematic review. Int J Dent Hyg. 2010 Nov;8(4):258-68.

31. Outhouse TL, Al-Alawi R, Fedorowicz Z, Keenan JV. Tongue scraping for treating halitosis. Cochrane Database Syst Rev. 2006 19;(2):CD005519. [citado 27 jun 2011]. Disponível em: http://cochrane.bvsalud.org/cochrane/main. php?lib=COC\&searchExp =Tongue $\% 20$ and $\% 20$ scraping $\% 20$ and $\% 20$ for $\% 20$ and $\% 20$ treating $\% 20$ and $\% 20$ halitosis\&lang=pt.

32. Carvalho MD, Tabchoury CM, Cury JA, Toledo S, NogueiraFilho GR. Impact of mouthrinses on morning bad breath in healthy subjects. J Clin Periodontol. 2004 Feb;31(2):85-90.

33. Nogueira-Filho GR, Duarte PM, Toledo S, Tabchoury CP, Cury JA. Effect of triclosan dentifrices on mouth volatile sulphur compounds and dental plaque trypsin-like activity during experimental gingivitis development. J Clin Periodontol. 2002 Dec;29(12):1059-64.

34. Iwu CO, Akpata O. Delusional halitosis. Review of the literature and analysis of 32 cases. Br Dent J. 1990 Apr 7;168(7):294-6.

35. Rösing CK, Gomes SC, Bassani DG, Oppermann RV. Effect of chewing gums on the production of volatile sulfur compounds (VSC) in vivo. Acta Odontol Latinoam. 2009 Jun;22(1):11-4. 